\title{
Review: Bornu
}

Author(s): F. R. C.

Review by: F. R. C.

Source: The Geographical Journal, Vol. 43, No. 6 (Jun., 1914), p. 685

Published by: geographicalj

Stable URL: http://www.jstor.org/stable/1779159

Accessed: 20-06-2016 00:16 UTC

Your use of the JSTOR archive indicates your acceptance of the Terms \& Conditions of Use, available at

http://about.jstor.org/terms

JSTOR is a not-for-profit service that helps scholars, researchers, and students discover, use, and build upon a wide range of content in a trusted digital archive. We use information technology and tools to increase productivity and facilitate new forms of scholarship. For more information about JSTOR, please contact support@jstor.org.

The Royal Geographical Society (with the Institute of British Geographers), Wiley are collaborating with JSTOR to digitize, preserve and extend access to The Geographical Journal 
biographical notes in some cases), plants, minerals and place-names mentioned in the text.

\section{AFRICA.}

\section{BORNO.}

The Sultanate of Bornu.' Translated from the German of Dr. A. Schultze, with additions and Appendices by P. Askell Benton, B.A., Third Class Resident, Bornu Province. Humphrey Milford, Oxford University Press. 1913. Maps. 7s. $6 d$. net.

It is a pleasure to have Dr. Schultze's monograph on Bornu in an English dress ; the pleasure is enhanced and the value of the volume much increased by the numerous additions made by Mr. Benton, perhaps the most diligent British student of Bornu matters. Dr. Schultze dealt with history, topography, climate, flora, fauna, ethnology, and commerce, and gave a list of authorities. Mr. Benton has added largely to the bibliographical entries, prints lists of the Bornu kings-one drawn up by Mr. Vischer, another, hitherto unpublished, made by a Bornese mallam. In other appendices relevant material from the 'Documents Scientifiques de la Mission Tilho' is translated into English; there is an account of Rabeh from the German, by Julius Lippert, some Kanuri derivations, and other matter. With praiseworthy zeal Mr. Benton has again consulted that mine of curious information the Tripoli Correspondence of the Foreign Office, as also the archives of our own Society, for personal details concerning Oudney, Denham, Clapperton, and other early explorers, and the result is fifty pages of unpublished correspondence, pages which help greatly to visualize for us the men who opened the road to the Central Sudan. Mr. Benton is keenly interested in these gallant pioneers ; one wonders if he is acquainted with Disraeli's reference to Denham and Clapperton in 'Vivian Grey,' published a few weeks after the appearance of the 'Narrative of Travels and Discoveries in Northern and Central Africa.'

The greater part of the old sultanate of Bornu lies within the British protectorate of Nigeria, and with wise handling we may expect it to recover much of its lost importance. A considerable future may also be predicted for German Bornu. Therefore, this volume, which gives all that the busy man need know about the country and its inhabitants, is doubly welcome. At some, perhaps not long distant, date Bornu will be linked by railway with the Niger, with the Kamerun coast, and with the Nile. Its agricultural and pastoral wealth will be greatly increased, and its commerce vastly developed. There is, Nachtigal declared, "scarcely any country in Central Africa which, if the efforts of mankind corresponded to the powers of the soil, offers a more beneficent prospect of rapid development." It is to this land that Mr. Benton provides an admirable handbook.

Scrupulous accuracy marks, in general, Mr. Benton's citations. It is to be regretted that he writes of the "Journal of the Royal Geographical Society," when he means the "Geographical Journal." It might cause confusion with the series that ended in 1880 .

$$
\text { F. R. C. }
$$

\section{Dry-farming in South Africa.}

'The Conquest of the Desert.' By William MacDonald. London: T. Werner Laurie, Ltd. 1913. Pp. 197. Photographs. 7s. 6d.

"The last Romance of Agriculture, the most daring of its many triumphs, is the Conquest of the Desert." In this fashion, Dr. MacDonald opens his account of the development of Gordonia at the expense of the Kalahari. Such progress

No. VI.-JUNE, 1914.] 